\title{
Antimicrobial resistance genes in Salmonella and Escherichia coli isolates from chicken droppings in Nairobi, Kenya
}

\author{
Lydia Mali Langata ${ }^{1 *}$, John M. Maingi ${ }^{1}$, Harry Asena Musonye ${ }^{1}$, John Kiiru² and Anthony Kebira Nyamache ${ }^{1}$
}

\begin{abstract}
Objective: Increase in antimicrobial resistance is a threat to health sector globally. Surveillance on the spread and emergence of antimicrobial resistance is therefore invertible. This study investigated prevalence of Salmonella and Escherichia coli, molecularly characterized their antimicrobial resistance patterns and spread among resistant isolates from chicken droppings.

Results: A total of 150 chicken households were selected randomly within Nairobi and fresh chicken droppings collected. Salmonella and Escherichia coli were isolated and antimicrobial susceptibility test carried out. Beta-lactamase genes and class 1 integrons were determined among amoxicillin resistant isolates. Isolates carrying TEM gene were further subjected to (GTG) $)_{5}$ PCR genotyping. Of the analysed samples, 57\% and 12\% contained Escherichia coli and Salmonella respectively. Most of the isolates were susceptible to the tested antibiotics with exemption of $53 \%$ of the isolates that were resistant to amoxicillin. The isolates were detected with TEM (46\%), CTX-M (18\%) resistance genes and class 1 integrons (25\%). The study reveals presence of beta-lactamase genes and class 1 integrons across Salmonella and Escherichia coli isolates from droppings of reared chicken. Therefore, the wide distribution of chicken and their fecal waste is likely to increase development of antibiotic resistance.
\end{abstract}

Keywords: Beta-lactamase genes, Class 1 integrons, Clonal expansion

\section{Introduction}

Increase in drug resistance to frequently used antimicrobial agents in human and animal production is a public health challenge globally $[1,2]$. It is estimated that by 2050, drug resistant infections are likely to cause death of 10 million people annually, if the current trends of antimicrobial resistance persist [1]. Regardless of this, global efforts to address this have generally been slow and inadequate to combat antimicrobial resistance [3]. Worldwide, there has been an increase in consumption of antibiotics [4]. Currently, the world health organization has reported high levels of antimicrobial resistance, indicating a strong correlation with the scale of antibiotic consumption [5]. The reports have indicated high

\footnotetext{
*Correspondence: mali.langata@gmail.com

1 Department of Microbiology, Kenyatta University, P.O Box 43844 , Nairobi 00100, Kenya

Full list of author information is available at the end of the article
}

antibiotic resistance levels in Escherichia coli and Salmonella among other bacteria. Nevertheless, other factors like suboptimal treatments, self-prescriptions, drug non adherences, have also promoted development of drug resistance [6].

In the recent past, antibiotics have been used widely in poultry production as growth promoters, prophylaxis and therapeutics [7]. Due to increase in demand for poultry, production of poultry could increase yearly by $3.6 \%$ in developing countries up to 2030 [8]. This suggests that the intensive poultry keeping will simultaneously increase use of antibiotics more than in human use [9]. It can also be observed that with disposal of poultry products in the environment, poor hygiene and ability of bacteria to remain in the environment, all this could likely contribute to dissemination of drug resistance variants strains $[7,10]$.

In Kenya, as in most of the developing countries, poultry farming is one of the widespread livestock

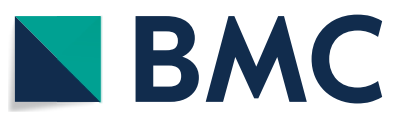

C The Author(s) 2019. This article is distributed under the terms of the Creative Commons Attribution 4.0 International License (http://creativecommons.org/licenses/by/4.0/), which permits unrestricted use, distribution, and reproduction in any medium, provided you give appropriate credit to the original author(s) and the source, provide a link to the Creative Commons license, and indicate if changes were made. The Creative Commons Public Domain Dedication waiver (http://creativecommons.org/ publicdomain/zero/1.0/) applies to the data made available in this article, unless otherwise stated. 
enterprises. Survey studies have revealed that Kenya has approximately 37 million birds. It is reported that about $65 \%$ of Kenyan households keep chicken, with Nairobi having the highest number of chicken kept per household [11]. The chicken are often administered antibiotics for prevention and treatment of diseases [12, 13]. Previous studies on antimicrobial resistance have revealed high resistance levels in bacterial isolates from rectal swabs of Kenyan chicken [14, 15]. However, much less has been investigated on the associated antimicrobial resistance genes.

This study determined prevalence of Salmonella and $E$. coli, their antimicrobial resistance patterns, associated resistance genes, class 1 integrons and clonal expansion of resistant isolates from chicken droppings in Nairobi, Kenya.

\section{Main text Methods Sampling}

Between September and December 2017, 150 chicken households were randomly selected from slum settings of Kawangware, Kibera, Mukuru, Kariobangi, Dandora and Mathare in Nairobi, Kenya. From each household, fresh chicken dropping samples were collected. Based on previous prevalence reported in a related study [14], the number of samples collected was adequate to ensure isolation of Escherichia coli and Salmonella. Ethics approval was not required for there was no direct contact with the chicken. The chicken droppings were collected from the environment. The study was approved by Kenya National Commission for Science, Technology and Innovation. Informed verbal consent was obtained from farmers rearing chicken to allow samples to be collected from their households. The sampled chicken droppings were from broilers, layers and those caged within the sampled households.

Isolation and identification of Salmonella and Escherichia coli Approximately $10 \mathrm{~g}$ of each sample of chicken droppings were enriched overnight in selenite $F$ broth and buffered peptone broth. Selenite enriched samples were subcultured onto Xylose Lysine Deoxycholate while buffered peptone enriched samples inoculated onto Eosin Methylene Blue agar media and the cultures incubated at $37^{\circ} \mathrm{C}$ for $24 \mathrm{~h}$. These organisms were further confirmed with biochemical tests as earlier described [16, 17].

\section{Antimicrobial susceptibility test}

Disc diffusion method was used to determine the susceptibility of isolates to antibiotics [18]. The following antimicrobial agents; gentamicin $(10 \mu \mathrm{g})$, streptomycin $(10 \mu \mathrm{g})$, amoxicillin $(30 \mu \mathrm{g})$, nalidixic acid $(30 \mu \mathrm{g})$, ciprofloxacin $(30 \mu \mathrm{g})$, chloramphenicol $(30 \mu \mathrm{g})$, co-trimoxazole $(25 \mu \mathrm{g})$ and tetracycline $(30 \mu \mathrm{g})$ were tested and Escherichia coli ATCC 25922 used as control. Results were interpreted in accordance with Clinical and Laboratory Standards Institute guidelines [19].

\section{Bacterial DNA extraction}

For the organisms that were confirmed resistant to amoxicillin, the isolates were further subjected to molecular characterization for the identification of resistance genes associated with amoxicillin resistance. The bacterial DNA was extracted by use of boiling-centrifugation method as earlier described [20], with few modifications. A loop full of overnight bacterial culture was suspended in $1000 \mu \mathrm{l}$ of sterile distilled water and then boiled for 15 min at $95{ }^{\circ} \mathrm{C}$ in a heating block. The resulting suspension was then centrifuged for $5 \mathrm{~min}$ at $14,000 \mathrm{rpm}$. The supernatant was used as DNA template.

\section{Characterization of resistance genes and class 1 integrons}

Resistance genes that encode resistance to beta-lactams; TEM (temoneira), SHV (sulphydryl variable enzyme), OXA (oxacillin hydrolyzing capabilities), CTX-M (cefotaximase-Munich) and class 1 integrons were screened as previously described $[21,22]$. Polymerase chain reaction amplification was confirmed by visualization with ethidium bromide staining of the gel.

\section{Genotyping of isolates carrying TEM genes}

Isolates carrying TEM were analysed using (GTG) 5 genotyping method [23]. Amplicons were electrophoresed and the fingerprint banding patterns recorded. Cluster analysis was done using GelCompar II software using UPFG arithmetic mean and dice correlation.

\section{Results}

Over $57 \%$ of the total sampled chicken droppings were found to harbor Escherichia coli. However, of the 150 samples, $12 \%$ were detected with Salmonella.

Escherichia coli isolates showed resistance to all antibiotics tested except to gentamicin and ciprofloxacin. Out of the 85 Escherichia coli isolates, the highest resistance observed was to amoxicillin $54 \%$ and the least was $2 \%$ for nalidixic acid and chloramphenicol. Intermediates were also common in all antibiotics tested within the range of $1 \%$ to $24 \%$ (Table 1 ).

The percentage of resistance to the antibiotics differed among the Salmonella isolates, $50 \%$ of the isolates were resistant to amoxicillin. Resistance to co-trimoxazole, tetracycline and streptomycin was 28\%, $11 \%$ and $6 \%$ respectively. None of the isolates were resistant to gentamicin, nalidixic acid, ciprofloxacin and 
Table 1 Antimicrobial susceptibility profiles of Escherichia coli

\begin{tabular}{llcc}
\hline Antibiotics & $\begin{array}{l}\text { Susceptible } \\
\text { No. (\%) }\end{array}$ & $\begin{array}{l}\text { Intermediate } \\
\text { No. (\%) }\end{array}$ & $\begin{array}{l}\text { Resistant } \\
\text { No. (\%) }\end{array}$ \\
\hline Streptomycin & $64(75)$ & $13(15)$ & $8(9)$ \\
Gentamicin & $83(98)$ & $2(2)$ & $0(0)$ \\
Chloramphenicol & $69(81)$ & $14(17)$ & $2(2)$ \\
Nalidixic acid & $71(84)$ & $12(14)$ & $2(2)$ \\
Ciprofloxacin & $84(99)$ & $1(1)$ & $0(0)$ \\
Tetracycline & $55(65)$ & $20(24)$ & $10(12)$ \\
Amoxicillin & $23(27)$ & $16(19)$ & $46(54)$ \\
Co-trimoxazole & $52(61)$ & $11(13)$ & $22(26)$ \\
\hline
\end{tabular}

Table 2 Antimicrobial susceptibility profiles of Salmonella

\begin{tabular}{llll}
\hline Antibiotics & $\begin{array}{l}\text { Susceptible } \\
\text { No. (\%) }\end{array}$ & $\begin{array}{l}\text { Intermediate } \\
\text { No. (\%) }\end{array}$ & $\begin{array}{l}\text { Resistant } \\
\text { No. (\%) }\end{array}$ \\
\hline Streptomycin & $12(67)$ & $5(28)$ & $1(6)$ \\
Gentamicin & $18(100)$ & $0(0)$ & $0(0)$ \\
Chloramphenicol & $18(100)$ & $0(0)$ & $0(0)$ \\
Nalidixic acid & $17(94)$ & $1(6)$ & $0(0)$ \\
Ciprofloxacin & $18(100)$ & $0(0)$ & $0(0)$ \\
Tetracycline & $11(61)$ & $5(28)$ & $2(11)$ \\
Amoxicillin & $2(11)$ & $7(39)$ & $9(50)$ \\
Co-trimoxazole & $8(44)$ & $5(28)$ & $5(28)$ \\
\hline
\end{tabular}

chloramphenicol. A higher percentage of intermediate isolates $39 \%$ was observed in amoxicillin (Table 2).

Among the bacteria screened for resistance genes, TEM and CTX-M were present. SHV and OXA were not detected among the resistant isolates. The TEM genes were detected in $46 \%$ of the 55 resistant isolates analysed. The TEM gene predominated followed by CTX-M $18 \%$ out of 55 isolates. Integrase genes in class 1 integrons were detected in $26 \%$ isolates among the 55 isolates tested (Table 3) (Additional file 1: Figure S1).

Isolates type-able were evaluated to determine their genetic relatedness. Some isolates had different $(\mathrm{GTG})_{5}$ patterns while others possessed similar $(\mathrm{GTG})_{5}$ patterns. Construction of dendogram from $(\mathrm{GTG})_{5}$ profiles of the isolates, separated the isolates into various clusters. Some of the isolates were clustered together despite from different sampling sites (Additional file 2: Figure S2 and Additional file 3: Figure S3).

\section{Discussion}

The results showed $57 \%$ prevalence of $E$. coli in chicken droppings obtained from broilers and layers. This differed from other related studies. In Kenya, a prevalence of $67 \%$ and $100 \%$ was reported in rectal swabs of indigenous and caecal samples of broiler chicken respectively $[14,24]$. Prevalence of $99 \%$ was reported in Grenada [25]. Mixed infection of samples with other microbes has been reported to affect prevalence of some bacteria such as E. coli and this could possibly be the cause of different prevalence from other studies. Environmental conditions, geographical location and other host factors affect prevalence of $E$. coli among related animals and could also account for the differences [26].

The study revealed $12 \%$ occurrences of Salmonella in collected samples. The detection level of Salmonella was higher compared to related study carried out in Kenya. The study reported a prevalence of $3.6 \%$ in chicken rectal swabs [15]. The variation in prevalence can be related to difference in hygiene practices among the chicken farmers. In addition, direct transmission of the bacteria from humans as well as difference in contamination levels of poultry feeds may be used to justify. In contrast to this study, other studies have reported prevalence higher than $20 \%$. In Uganda and Nigeria, prevalence of $21 \%$ and $23 \%$ were observed respectively [27, 28]. Studies carried out in Burkina Faso and Gambia reported prevalence of 55\% and $67 \%$ respectively $[29,30]$. The prevalence of Salmonella in poultry has been demonstrated to differ depending on country, the type of production methods and measures used to control contamination [29].

Different resistance patterns of Escherichia coli and Salmonella isolates to antibiotics tested in the current study are in consistence with previous related studies on antimicrobial resistance [31-33]. The patterns reflect resistance to commonly used antibiotics including amoxicillin, co-trimoxazole, tetracycline, streptomycin and low resistance to ciprofloxacin and chloramphenicol. In Kenya, studies have reported extensive use of tetracycline and sulphonamides such as co-trimoxazole in poultry

Table 3 Carriage of antimicrobial resistance genes (number, \%) among the isolates

\begin{tabular}{|c|c|c|c|c|c|c|c|}
\hline & \multicolumn{7}{|c|}{ Distribution of antimicrobial resistance genes among 55 isolates } \\
\hline & TEM only & TEM + CTX-M & All TEM & CTX-M only & All CTX-M & OXA & SHV \\
\hline Presence of class 1 integrons & 10 & 2 & 12 & 2 & 4 & 0 & 0 \\
\hline Absence of class 1 integrons & 11 & 2 & 13 & 4 & 6 & 0 & 0 \\
\hline Total & $21(38 \%)$ & $4(7 \%)$ & $25(46 \%)$ & $6(11 \%)$ & $10(18 \%)$ & 0 & 0 \\
\hline
\end{tabular}


$[12,13]$. Despite this, similar to the current study, studies have reported resistance to beta-lactams in addition to tetracycline and co-trimoxazole [14, 15, 25]. Moreover, the current study recorded higher resistance to amoxicillin. This demonstrates that apart from therapeutic use of antibiotics in poultry, other factors influence development of antibiotic resistance.

Beta-lactamase genes were detected among the isolates. These genes have previously been detected in poultry [34-36]. The TEM gene predominated followed by CTX-M; this was similar to previous study in Nigeria that reported prevalence of $63 \%$ and $35 \%$ of TEM and CTX-M respectively in isolates from chicken droppings [34]. In contrast, high prevalence of OXA has been reported in Algeria while in Germany the predominant beta-lactamase gene was CMY-2 and SHV [37, 38]. In Zambia, the most prevalent was CTX-M. This justify that resistance gene prevalence in bacterial isolates from poultry varies across the world [36]. Even though resistance to amoxicillin is significantly related to the presence of a betalactamase gene, some isolates that were resistant to this antibiotic did not have the resistance genes. This could imply that some of the isolates carry beta-lactamase genes different from the ones that were screened in this study. Since most of the common beta-lactamase genes were screened, resistance to amoxicillin could have been caused by other resistance mechanisms. The detected beta-lactamase genes, among reared chicken for food, pose a threat to disease infections caused by these organisms and related. These findings suggest that the high rate of disposal of chicken droppings in the environment is likely to accelerate the rate of spread of antimicrobial resistance genes.

Most of the class 1 integrons were detected in beta-lactamase positive isolates. The results of this study support previous findings that some of beta-lactamase genes are located within integron as gene cassettes $[21,39,40]$. The results demonstrate that integrons are widespread among bacterial communities in chicken droppings. The genetic context of class 1 integron is linked with dissemination of antibiotic resistance genes [41]. Therefore, presence of these integrons in the current study suggests high rate of transfer of resistance genes from chicken droppings.

Similarities in genetic profiles among E. coli and Salmonella isolates carrying TEM gene from different locations may be linked to clonal expansion of these bacteria. Some resistant genes have been reported to spread through clonal expansion of antimicrobial resistant bacteria $[42,43]$. However, some of the bacterial isolates were not closely related when subjected to (GTG) $)_{5}$ PCR typing despite from the same sampling site. This implies that the resistance genes could have been gained through independent genetic mechanisms, possibly selection for resistance following exposure to antibiotics and through horizontal gene transfer. Previously, resistance caused by expansion of clones and independent strains has been described [42]. This indicated that antimicrobial resistance is a consequence of complex interactions involved in spread of resistance.

\section{Limitation}

The current study never determined the specific source of the resistance genes. It is important that further investigation be carried out to establish the source. Their acquisition could be through cross contamination from humans, prior exposure to antibiotics or from contaminated poultry feeds by resistant microorganisms.

\section{Additional files}

Additional file 1. Figure S1. PCR detection of TEM, CTX-M and integrase gene in class 1 integrons.

Additional file 2. Figure S2. Dendogram of TEM positive Escherichia coli isolates.

Additional file 3. Figure S3. Dendogram of TEM positive Salmonella isolates.

\section{Abbreviations}

TEM: temoneira; OXA: oxacillin hydrolysing capabilities; SHV: sulphydryl variable enzyme; CTX-M: cefotaximase-Munich hydrolysing capabilities.

\section{Authors' contributions}

LML was involved in designing of the study, sample collection, laboratory analysis, interpretation of data and drafting of the manuscript. HAM assisted in sample collection and data analysis. AKN and JMM conceptualized the idea, helped in designing of the experiment, and supervised the analysis of the samples, interpretation of data, and review of the article. JK supervised the laboratory experiment, analysis, and interpreted the results. All authors read and approved the final manuscript.

\section{Author details}

${ }^{1}$ Department of Microbiology, Kenyatta University, P.O Box 43844, Nairobi 00100, Kenya. ${ }^{2}$ Centre of Microbiology Research, Kenya Medical Research Institute, P.O Box 54840, Nairobi 00200, Kenya.

\section{Acknowledgements}

We would like to thank the poultry farmers for agreeing to participate and consent for us to collect chicken droppings samples of their chicken from households.

\section{Competing interests}

The authors declare that they have no competing interests.

Availability of data and materials

Not applicable.

Consent for publication

Not applicable.

\section{Ethics approval and consent to participate}

Ethical clearance was not required for the chicken droppings were collected from the environment. The study was approved by the Kenya National Commission for Science, Technology and Innovation. Informed verbal consent was obtained from farmers rearing chicken. 


\section{Funding}

Not applicable.

\section{Publisher's Note}

Springer Nature remains neutral with regard to jurisdictional claims in published maps and institutional affiliations.

Received: 4 December 2018 Accepted: 9 January 2019

Published online: 14 January 2019

\section{References}

1. O'Neill J. Tackling drug-resistant infections globally: final report and recommendations. In: Review of antimicrobial resistance. London: HM Government and Wellcome trust; 2016.

2. Pourmand A, Mazer-Amirshahi M, Jasani G, May L. Emerging trends in antibiotic resistance: implications for emergency medicine. Am J Emerg Med. 2017;35(8):1172-6.

3. World Health Organization. Worldwide country situation analysis: response to antimicrobial resistance. Geneva: World Health Organization; 2015.

4. Klein EY, Van Boeckel TP, Martinez EM, Pant S, Gandra S, Levin SA, Goossens H, Laxminarayan R. Global increase and geographic convergence in antibiotic consumption between 2000 and 2015. Proc Natl Acad Sci. 2018:2017:17295.

5. World Health Organisation. Global antimicrobial resistance surveillance system (GLASS) report. http://www.who.int/glass/resources/publications/ early-implementation-report/en/. Accessed 29 Jan 2018.

6. Dar OA, Hasan R, Schlundt J, Harbarth S, Caleo G, Dar FK, Littmann J, Rweyemamu M, Buckley EJ, Shahid M, Kock R. Exploring the evidence base for national and regional policy interventions to combat resistance. Lancet. 2016;387(10015):285-95. https://doi.org/10.1016/S0140 -6736(15)00520-6.

7. Manyi-Loh C, Mamphweli S, Meyer E, Okoh A. Antibiotic use in agriculture and its consequential resistance in environmental sources: potential public health implications. Molecules. 2018;23(4):795. https://doi. org/10.3390/molecules23040795.

8. FAO. Poultry in the 21 st Century: avian influenza and beyond. In: Proceedings of the international poultry conference, held 5-7 November 2007, Bangkok, Thailand. 2008.

9. Aarestrup FM. The livestock reservoir for antimicrobial resistance: a personal view on changing patterns of risks, effects of interventions and the way forward. Phil Trans R Soc B. 2015;370(1670):20140085.

10. Canteon R. Antibiotic resistance genes from the environment: a perspective through newly identified antibiotic resistance mechanisms in the clinical setting. Clin Microbiol Infect. 2009;15:20-5.

11. Omiti JM, Okuthe SO. An overview of the poultry sector and status of Highly Pathogenic Avian Influenza (HPAI) in Kenya: Background Paper International Food Policy Research Institute (IFPRI); 2009.

12. Muthuma EM, Gitau GK, Aboge GO. Antimicrobial usage in broiler farms in, peri-urban, Nairobi, Kenya. Am J Res Commun. 2016;4(8):14-29.

13. Mitema ES, Kikuvi GM, Wegener HC, Stohr K. An assessment of antimicrobial consumption in food producing animals in Kenya. J Vet Pharmacol Ther. 2001;24(6):385-90.

14. Wesonga SM, Muluvi GM, Okemo PO, Kariuki S. Antibiotic resistant Salmonella and Escherichia coli isolated from indiginous Gallus domesticus in Nairobi, Kenya. East Afr Med J. 2010;87(5):205-10.

15. Nyabundi D, Onkoba N, Kimathi R, Nyachieo A, Juma G, Kinyanjui P, Kamau J. Molecular characterization and antibiotic resistance profiles of Salmonella isolated from fecal matter of domestic animals and animal products in Nairobi. Trop Dis Travel Med Vacc. 2017;3(1):2.

16. Eguale T, Engidawork E, Gebreyes WA, Asrat D, Alemayehu H, Medhin G, Johnson RP, Gunn JS. Fecal prevalence, serotype distribution and antimicrobial resistance of Salmonellae in dairy cattle in central Ethiopia. BMC Microbiol. 2016;16(1):20.

17. Islam MM, Islam MN, Sharifuzzaman FM, Rahman MA, Sharifuzzaman JU, Sarker EH, Shahiduzzaman M, Mostofa M, Sharifuzzaman MM. Isolation and identification of Escherichia coli and Salmonella from poultry litter and feed. Int J Nat Soc Sci. 2014;1(1):1-7.
18. Bauer AW, Kirby WM, Sherris JC, Turck M. Antibiotic susceptibility testing by a standardized single disk method. Am J Clin Pathol. 1966:45(4):493-6.

19. Clinical Laboratory Standards Institute. Performance standards for antimicrobial susceptibility testing: 16th informational supplement, M100-S24, 2014, Wayne, PA, USA

20. Freschi CR, Oliveira CJ. Comparison of DNA-extraction methods and selective enrichment broths on the detection of Salmonella Typhimurium in swine feces by polymerase chain reaction (PCR). Braz J Microbiol. 2005;36(4):363-7.

21. Moghaddam MJ, Mirbagheri AA, Salehi Z, Habibzade SM. Prevalence of class 1 integrons and extended spectrum beta lactamases among multidrug resistant Escherichia coli isolates from north of Iran. Iran Biomed J. 2015;19(4):233.

22. Chishimba K, HangOmbe BM, Muzandu K, Mshana SE, Matee MI, Nakajima C, Suzuki Y. Detection of extended spectrum beta-lactamase producing Escherichia coli in market-ready chickens in Zambia. Int J Microbiol. 2016;2016:5.

23. Kathleen MM, Samuel L, Felecia C, Ng KH, Lesley MB, Kasing A. (GTG) 5-PCR analysis and $16 \mathrm{~S}$ rRNA sequencing of bacteria from Sarawak aquaculture environment. Int Food Res J. 2014;21(3):915-20.

24. Adelaide OA, Bii C, Okemo P. Antibiotic resistance and virulence factors in Escherichia coli from broiler chicken slaughtered at Tigoni processing plant in Limuru, Kenya. East Afr Med J. 2008;85(12):597-606.

25. Amadi VA, Watson N, Onyegbule OA, Matthew-Belmar V, Avendano E, Tiwari K, Sharma R, Hariharan H. Antimicrobial resistance profiles of Escherichia coli recovered from feces of healthy free-range chickens in Grenada, West Indies. Int J Curr Appl Sci. 2015;4(6):168-75.

26. Gordon DM, Cowling A. The distribution and genetic structure of Escherichia coli in Australian vertebrates: host and geographic effects. Microbiology. 2003;149(12):3575-86.

27. Odoch T, Wasteson Y, L'Abée-Lund T, Muwonge A, Kankya C, Nyakarahuka L, Tegule S, Skjerve E. Prevalence, antimicrobial susceptibility and risk factors associated with non-typhoidal Salmonella on Ugandan layer hen farms. BMC Veterinary Research. 2017;13(1):365.

28. Fagbamila IO, Barco L, Mancin M, Kwaga J, Ngulukun SS, Zavagnin P, Lettini AA, Lorenzetto M, Abdu PA, Kabir J, Umoh J. Salmonella serovars and their distribution in Nigerian commercial chicken layer farms. PLOS ONE. 2017;12(3):e0173097.

29. Kagambèga A, Lienemann T, Aulu L, Traoré AS, Barro N, Siitonen A, Haukka K. Prevalence and characterization of Salmonella enterica from the feces of cattle, poultry, swine and hedgehogs in Burkina Faso and their comparison to human Salmonella isolates. BMC Microbiol. 2013;13(1):253.

30. Dione MM, Ikumapayi UN, Saha D, Mohammed NI, Geerts S, leven M, Adegbola RA, Antonio M. Clonal differences between non-typhoidal Salmonella (NTS) recovered from children and animals living in close contact in the Gambia. PLoS Negl Trop Dis. 2011;5:1148.

31. Abbassi MS, Kilani H, Zouari M, Mansouri R, Oussama EF. Antimicrobial resistance in Escherichia coli isolates from healthy poultry, bovine and ovine in Tunisia: a real animal and human health threat. J Clin Microbiol Biochem Technol. 2017;3(2):019-123.

32. Rugumisa BT, Call DR, Mwanyika GO, Mrutu RI, Luanda CM, Lyimo BM Subbiah X, Buza JJ. Prevalence of antibiotic-resistant fecal Escherichia coli isolates from penned broiler and scavenging local chickens in Arusha, Tanzania. J Food Protect. 2016;79(8):1424-9.

33. Kariuki S, Dougan G. Antibacterial resistance in sub-Saharan Africa: an underestimated emergency. Ann NY Acad Sci. 2014;1323(1):43-55.

34. Akinbami OR, Olofinsae $S$, Ayeni FA. Prevalence of extended spectrum beta lactamase and plasmid mediated quinolone resistant genes in strains of Klebsiella pneumonia, Morganella morganii, Leclercia adecarboxylata and Citrobacter freundii isolated from poultry in South Western Nigeria. PeerJ. 2018;6:e5053.

35. Machado E, Cantón R, Baquero F, Galán JC, Rollán A, Peixe L, Coque TM. Integron content of extended-spectrum- $\beta$-lactamase-producing Escherichia coli strains over 12 years in a single hospital in Madrid, Spain. Antimicrob Agents Chemother. 2005;49(5):1823-9.

36. Saliu EM, Vahjen W, Zentek J. Types and prevalence of extended-spectrum beta-lactamase producing Enterobacteriaceae in poultry. Anim Health Res Rev. 2017;18(1):46-57.

37. Chabou S, Leulmi H, Davoust B, Aouadi A, Rolain JM. Prevalence of extended-spectrum $\beta$-lactamase-and carbapenemase-encoding genes 
in poultry faeces from Algeria and Marseille, France. J Glob Antimicrob Resistance. 2018;13:28-32.

38. von Tippelskirch P, Gölz G, Projahn M, Daehre K, Friese A, Roesler U, Alter T, Orquera S. Prevalence and quantitative analysis of ESBL and AmpC beta-lactamase producing Enterobacteriaceae in broiler chicken during slaughter in Germany. Int J Food Microbiol. 2018;281:82-9.

39. Mostafa M, Siadat SD, Shahcheraghi F, Vaziri F, Japoni-Nejad A, Yousefi JV, Rajaei B, Mood EH, Moshiri A, Siamdoust SA, Rahbar M. Variability in gene cassette patterns of class 1 and 2 integrons associated with multi drug resistance patterns in Staphylococcus aureus clinical isolates in TehranIran. BMC Microbiol. 2015;15(1):152.

40. Chowdhury PR, Ingold A, Vanegas N, Martínez ME, Merlino J, Merkier AK, Castro M, Rocha GG, Borthagaray G, Centrón D, Toledo HB. Dissemination of multiple drug resistance genes by class 1 integrons in Klebsiella pneumoniae isolates from four countries: a comparative study. Antimicrob Agents Chemother. 2011;AAC:01529.

41. del Castillo BR, Vinué L, Román EJ, Guerra B, Carattoli A, Torres C, MartínezMartínez L. Molecular characterization of multiresistant Escherichia coli producing or not extended-spectrum $\beta$-lactamases. BMC Microbiol. 2013;13(1):84

42. Namboodiri SS, Opintan JA, Lijek RS, Newman MJ, Okeke IN. Quinolone resistance in Escherichia coli from Accra, Ghana. BMC Microbiol. 2011:11(1):1.

43. Wimalarathna HM, Richardson JF, Lawson AJ, Elson R, Meldrum R, Little CL, Maiden MC, McCarthy ND, Sheppard SK. Widespread acquisition of antimicrobial resistance among Campylobacter isolates from UK retail poultry and evidence for clonal expansion of resistant lineages. BMC Microbiol. 2013;13(1):160
Ready to submit your research? Choose BMC and benefit from:

- fast, convenient online submission

- thorough peer review by experienced researchers in your field

- rapid publication on acceptance

- support for research data, including large and complex data types

- gold Open Access which fosters wider collaboration and increased citations

- maximum visibility for your research: over $100 \mathrm{M}$ website views per year

At BMC, research is always in progress.

Learn more biomedcentral.com/submissions 